\title{
Use of the over-the-counter drugs by adults and an assessment of the impact of advertisements on consumers
}

\section{Stosowanie leków dostępnych bez recepty przez osoby dorosłe oraz ocena wpływu reklamy na konsumentów}

\author{
Monika Szpringer¹, Marzena Olędzka², Justyna Kosecka³, Bogumił Sobczyk², Paulina Grabowska \\ ${ }^{1}$ Department of Social Prophylaxis, Institute of Public Health, Jan Kochanowski University, Kielce, Poland \\ Head of the Department: Prof. Monika Szpringer PhD \\ ${ }^{2}$ Polish Association of EMDR Teraphy \\ Head of the Association: Marzena Olędzka \\ ${ }^{3}$ Department of Pedagogy and Arts, Institute of Pedagogy and Psychology, Jan Kochanowski University, Kielce, Poland \\ Head of the Department: Prof. Sławomir Koziej PhD \\ ${ }^{4}$ District Sanitary-Epidemiological, Jędrzejowo, Poland \\ Head of the District: Barbara Ciechanowska
}

Key words: over-the-counter drugs, drugs without prescription, TV advertisement, sex, abuse.

Słowa kluczowe: leki dostępne bez recepty, reklama telewizyjna, płeć, nadużywanie.

\begin{abstract}
Introduction: During the last few years there has been a considerable value growth in the demand for the so-called over-thecounter drugs (OTC, available without doctor's prescription). Using OTC drugs is related to self-treatment, aimed at mitigating first symptoms of a cold, flu, or various types of pain. The omnipresent advertisements for OTC drugs encourage and contribute to the elevated demand. Unfortunately, the marketing techniques used in advertisements fail to provide reliable and objective information to the viewers about specific products.

Aim of the research: To determine the respondents' opinions on using OTC drugs and to assess how advertisements influence the consumers' needs.

Material and methods: The study was conducted by means of a diagnostic survey using a questionnaire. For the purpose of the study, the authors prepared a survey questionnaire, which was used as a research tool. The study included 114 respondents, falling within an age bracket of 18-66 years.

Results: The most frequently used OTC drugs were painkillers and medicines for cold and flu symptoms $(68.33 \%$ of women and $59.09 \%$ of men). The drugs were usually bought in pharmacies and grocery/convenience stores.

Conclusions: Taking OTC drugs is a widespread phenomenon, both in women and men. The obtained results clearly indicate that advertisements have a considerable impact upon target groups and contribute to increased consumption of OTC drugs.
\end{abstract}

\section{Streszczenie}

Wprowadzenie: Krajowy rynek farmaceutyczny w ostatnich latach notuje wzrost zapotrzebowania na produkty z kategorii leków dostępnych bez recepty (OTC). Stosowanie tych leków wiąże się z samoleczeniem w celu złagodzenia pierwszych objawów przeziębienia i grypy, różnego pochodzenia bólu, a także problemów ze snem i objawów stresu. Przyczynia się do tego wszechobecna reklama leków OTC w środkach masowego przekazu. Niestety ze względu na stosowane techniki marketingowe reklamy leków OTC nie są w stanie zapewnić odbiorcom przekazu obiektywnych informacji na temat konkretnego produktu.

Cel pracy: Poznanie opinii badanych dotyczących stosowania leków OTC oraz ocena wpływu reklamy na zapotrzebowanie konsumentów.

Materiał i metody: Zastosowano metodę sondażu diagnostycznego, w ramach którego wykorzystano technikę ankietowania. Na potrzeby tego badania skonstruowano autorski kwestionariusz ankiety. Badaniem objęto ogółem 114 osób w wieku 18-66 lat.

Wyniki: Spośród leków OTC badani najczęściej stosowali leki przeciwbólowe oraz leki na objawy przeziębienia i grypy (68,33\% kobiet i 59,09\% mężczyzn). Głównymi miejscami zakupu leków były apteka oraz sklepy spożywcze.

Wnioski: Stosowanie leków OTC jest zjawiskiem powszechnym zarówno wśród kobiet, jak i mężczyzn. Wyniki badań jednoznacznie wskazują, że reklama wywiera duży wpływ na odbiorców i przyczynia się do zwiększonej konsumpcji leków OTC. 


\section{Introduction}

During the last few years there has been a noticeable, constantly growing demand for medicines available without a doctor's prescription (over-the-counter drugs, OTC). The phenomenon is said to have begun along with the start of the political and economical transformations in the 1990s. Since then, sales of the OTC drugs in Poland have been constantly growing, with an estimated annual sales growth of $3 \%[1,2]$. The OTC pharmacotherapy is supposed to enable self-treatment, which, however, is only then possible when consumers have access to efficient and safe, but also modern, drugs [3]. Currently, OTC drugs are broadly used for self-treatment. Unfortunately, many consumers use such products not only in minor somatic indispositions, but also in more severe or even chronic disorders. According to some reports of 2006 regarding self-treatment in Brazil, as many as 80 million people used OTC drugs for self-treatment purposes in 1994 [4, 5]. In addition, as revealed by a study among laryngological patients, as many as $83 \%$ of them were buying or using drugs without prescription. The same study indicated that women were more eager to use OTC drugs than men $(58 \%$ and $42 \%$, respectively) [6].

In contemporary times, the widespread use of OTC drugs constitutes a significant threat to public health. Frequent use of "safe" OTC drugs may lead to overdose, and, in the case of particularly vulnerable individuals, a safe dose may be toxic. Another important issue is the combination of OTC drugs with those prescribed by doctors - very often patients fail to inform doctors about the OTC drugs they use. Unreasonable use of painkillers may cause serious consequences, including intoxication, severe liver damage, addiction, and even death [7-9]. Still, it is to be expected that the outcome of the expanding pharmaceutical market and advertisements will be increased consumption of painkillers as well as sleeping and tranquilising medicines [10-12].

Researchers in the field of addictions stress that using drugs without prescription is currently more and more popular, becoming a specific trend among young people [13]. Reports from other countries indicate that respondents described paracetamol as a safe and harmless medicine, whereas some foreign studies suggest clearly that paracetamol, if used inappropriately, may result in serious health complications [14]. The studies in various countries show that the drugs most frequently used by young people are cough and cold medicaments. In larger amounts, they have a similar effect to narcotics. The data of the American coroner clearly states that the number of deaths among young people (12-25 years age bracket) related to overdose of medicines (including OTC drugs) is continuously growing. Between 2005 and 2006, the death rate increased from $10 \%$ to $12-20 \%$ [15]. More- over, many young people are convinced that using available OTC drugs is much safer and less likely to induce health complications than taking illegal psychoactive drugs. However, excessive consumption of OTC drugs, particularly combined with narcotics or alcohol, may even be fatal [16].

One of the means to promote drugs is advertising, with massive amounts of broadcasting in mass media [17]. The $21^{\text {st }}$ century is the period of information overload and the power of the media. Medicines are advertised on almost all TV stations, and commercials are the most lucrative medium. Pharmaceutical companies and corporations spend ca. 70\% of their expenses for advertising of OTC drugs, as this type of publicity generates the highest profit [18].

\section{Aim of the research}

The aim of this article is to determine the opinions of the respondents as regards the use of OTC drugs, as well as the impact of commercials on consumer demand.

\section{Material and methods}

In order to assess the phenomenon of using OTC drugs, the authors applied the method of a diagnostic survey, with their own questionnaire as a research tool. The questionnaire comprised 31 questions, referring to the issue of OTC drug abuse as well as the impact of commercials upon the consumers. The statistical analysis of the data was made using MS Excel 2007 software. The study was conducted between November 2012 and January 2013 among adult inhabitants of the Świętokrzyskie region. The surveyed group comprised adults in the 18-66 years age bracket. In total, the study included 114 respondents.

\section{Results}

The study comprised a group of 114 adult inhabitants of the Świętokrzyskie region, of which 55\% were women $(n=63)$ and $45 \%$ were men $(n=51)$. Among the women, the largest age group was aged $18-25$ years $(41.26 \%)$, whereas in men it was $26-35$ years $(31.37 \%)$. Among the respondents, people declaring higher education were the most numerous both among women and men (63.49\% and $35.29 \%$, respectively), whereas the least numerous was the group with elementary education (3.92\% of men).

Among all the respondents, a group of ten people was distinguished, who claimed that they used no OTC drugs at all. This group constitutes only $8.77 \%$ of all respondents, which already at this stage may indicate the seriousness of the problem of buying OTC drugs. While replying to the question: "Do you buy OTC drugs?", as many as $71.43 \%$ of women and $47.06 \%$ of men declared that they did it on a regular basis $(p<0.02)$ (Figure 1$)$ 


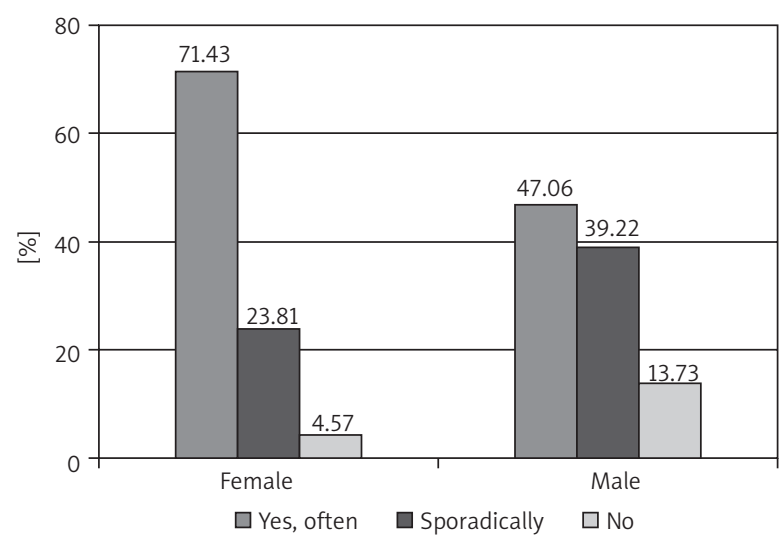

Figure 1. The buying of OTC drugs by respondents

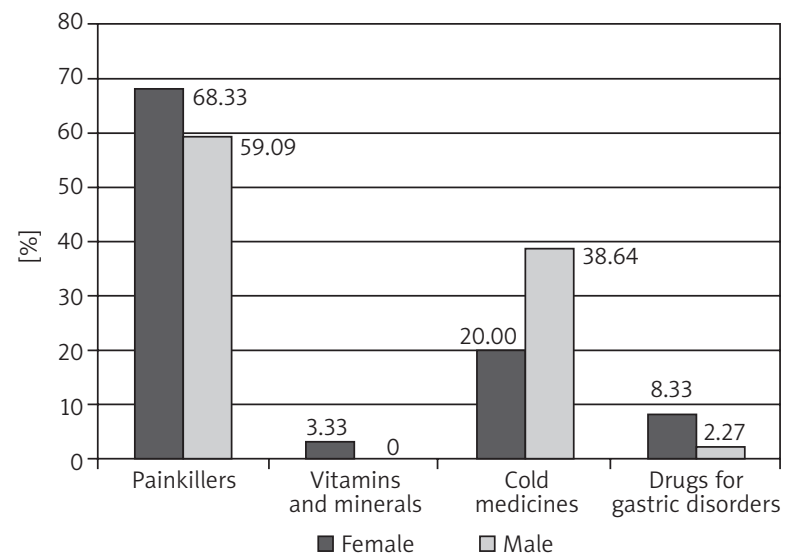

Figure 3. The most frequently bought types of OTC drugs

The respondents were asked to indicate the places where they buy OTC drugs most frequently. From the obtained data, three such places were identified. The highest number of women and men bought the OTC drugs in pharmacies $(83.33 \%$ and $63.64 \%$, respectively). It has been observed that men much more often than women buy medicines from shops (27.27\%). This relation is statistically relevant $(p<0.04)$ (Figure 2 ).

The respondents were then asked to indicate the OTC drugs that they purchased most often. The highest percentage declared that they bought painkillers (68.33\% of women and $59.09 \%$ of men), followed by medicines for colds (20.00\% of women and $28.64 \%$ of men). Interestingly, none of the male respondents declared to have bought vitamins and minerals $(p>0.05)$ (Figure 3).

The results referring to the frequency of using OTC drugs by the respondents are statistically relevant $(p<0.0001)$. These results are disturbing, since as many as $6.67 \%$ of women and $4.55 \%$ of men take OTC medicines every day. In addition, $5.00 \%$ of women and nearly $19.00 \%$ of men take such drugs once per week. Given that $26.67 \%$ of women and $11.36 \%$ of

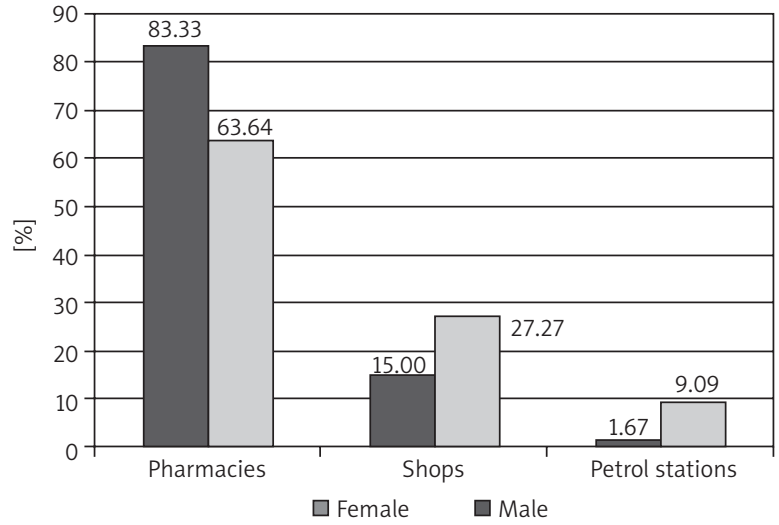

Figure 2. Places where respondents usually buy OTC drugs

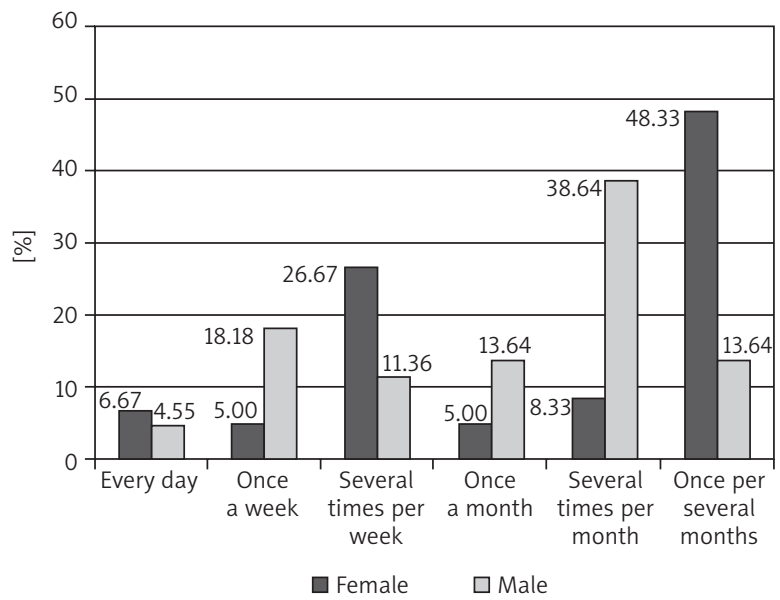

Figure 4. Frequency of using OTC drugs by respondents

men use medicines several times per week, the results show the scale of the use of drugs without prescription (Figure 4).

The respondents were asked to express their opinion about the factors determining their choice of specific drugs. Upon the obtained information, it is possible to identify two such factors. In women, the highest percentage of respondents pointed at commercials $(45.00 \%)$, whereas in men it was the price $(43.18 \%)$ $(p>0.05)$. The detailed results are presented in Figure 5.

The results regarding inclination towards selftreatment are also disturbing. When answering the question: "Do you feel capable of curing pain or cold symptoms with OTC drugs?" the significant majority replied that they had comprehensive knowledge about the matter. Only around a quarter of the respondents said they would ask a specialist for an advice $(p>0.05)$ (Figure 6).

The scale of the self-treatment is reflected by the data regarding the consultation of buying medications with a specialist. In this case, only $8.33 \%$ of 


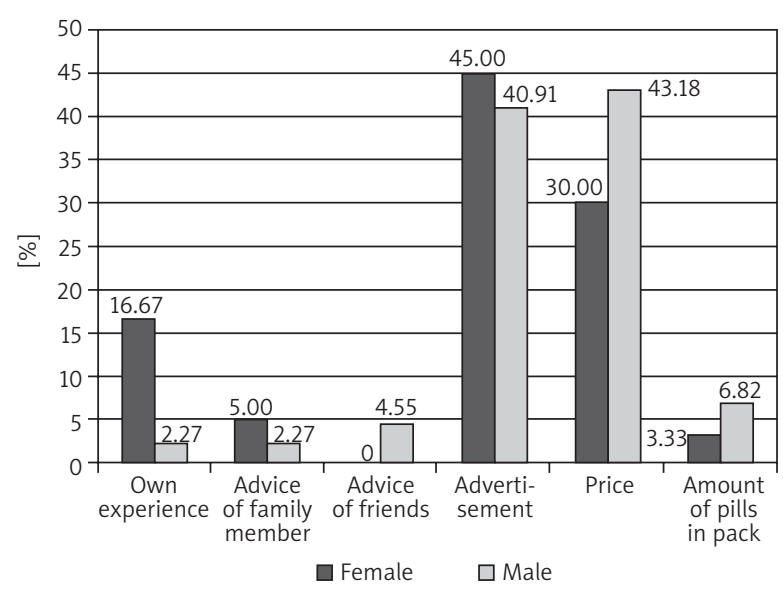

Figure 5. Factors determining the choice of OTC drugs, as stated by respondents

women and $4.55 \%$ of men consulted with a doctor or a pharmacist about which remedy to buy $(p>0.05)$ (Figure 7).

Another task given to the respondents was to point out the situations in which they buy OTC drugs most frequently. The obtained results reveal that the largest number of the respondents buy medicines just in case (nearly $47 \%$ of women and $46 \%$ of men). What is important, more than $30 \%$ of both women and men stated that their decision to buy a specific medicine was determined by a commercial presenting such a drug. It is alarming that those respondents who only then buy drugs when symptoms of a disease occur represent the smallest percentage of all $(p>0.05)$ (Table 1).

The largest proportion of the respondents declared that they often watch TV commercials $(71.43 \%$ of women and $50.98 \%$ of men), with only one man stating he does not do it at all $(1.96 \%)(p>0.05)$. The opinions of the respondents about the reliability of the information provided in the commercials were considerably varied. A significant majority claimed that such information is unreliable $(69.84 \%$ of women and $50.98 \%$ of men). However, in the group that trusts the commercials, men are in the majority (27.45\%). This relation is statistically relevant $p=0.001$. A detailed description is presented in Figure 8. Moreover, in the opinion of the respondents, commercials provide

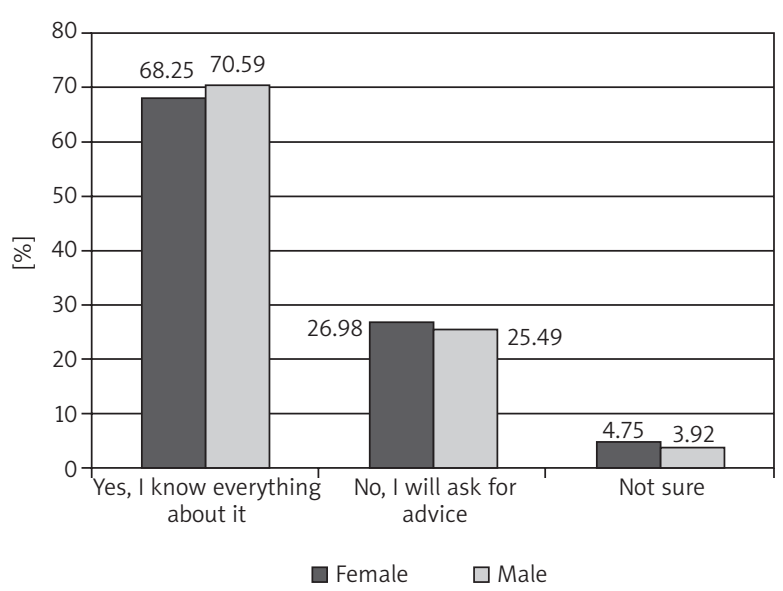

Figure 6 . Inclinations towards self-treatment among the respondents

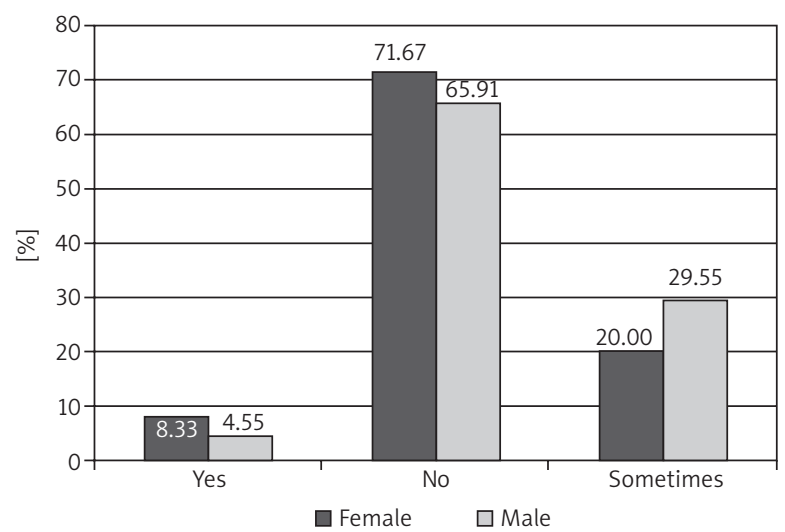

Figure 7. Do respondents consult about buying OTC drugs with doctors or pharmacists?

a sufficient amount of detail as regards the effects and use of the medicines $(79.37 \%$ of women and $43.14 \%$ of men). It has been noted that the opinions of men are much more varied. In addition, only $3.17 \%$ of women and $5.88 \%$ of men thought that advertisements fail to provide sufficient information about medicines. This relation is statistically relevant $p=0.00008$.

The respondents were asked to indicate a colour associated with a quick and strong effect of a medicine. The majority chose red $(92.06 \%$ of women and

Table 1. Situations in which respondents buy OTC drugs

\begin{tabular}{|lcccc|}
\hline In which situations do you buy OTC drugs? & \multicolumn{2}{c|}{ Female } & \multicolumn{2}{c|}{ Male } \\
\cline { 2 - 5 } & $n$ & $\%$ & $n$ & $\%$ \\
When symptoms occur & 11 & 18.33 & 9 & 20.45 \\
Just in case & 28 & 46.66 & 20 & 45.45 \\
After watching a commercial presenting the drug & 21 & 35.00 & 15 & 34.09 \\
Total & 60 & 100 & 44 & 100 \\
\hline
\end{tabular}




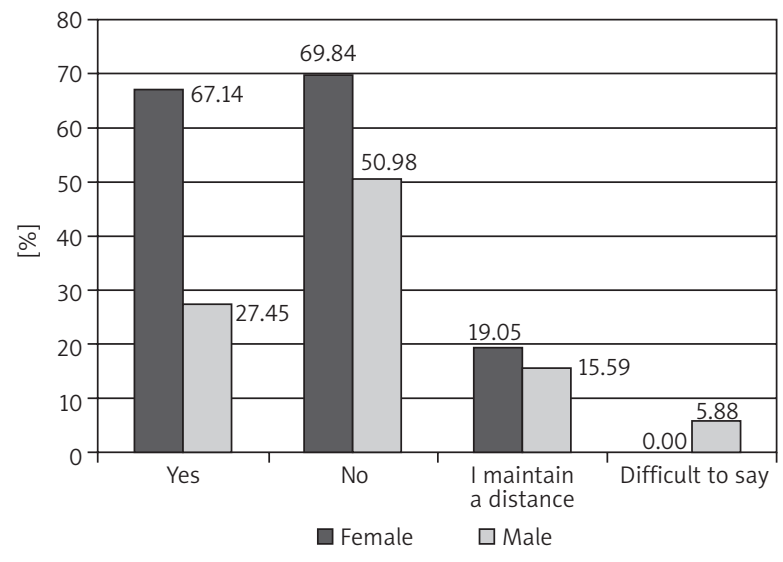

Figure 8. Opinions of respondents on the reliability of information provided in OTC drug advertisements

$88.24 \%$ of men) ( $p>0.05)$. Moreover, the study participants claimed that the most accepted forms of a medicine are pills (58.33\% of women and $68.18 \%$ of men) and syrups (33.33\% of women and $15.91 \%$ of men). The least favourite form is suppositories, only indicated by $1.67 \%$ of female respondents $(p>0.05)$.

\section{Discussion}

Currently, new threats to public health are gaining attention. Undoubtedly, excessive consumption of OTC drugs is such a threat, both in Poland and across the globe. Thus, the question of unnecessary consumption of OTC drugs has become a subject of numerous studies. Likewise, the role of mass media is important in the discourse, which broadcasts commercials of such drugs.

As indicated by the results of our own studies, there is constant growth of interest in OTC drug consumption. It is important to notice the difference in frequency of buying OTC drugs by women and men. It seems that the observed growth may show a specific "fashion" of using such medicines. A retrospective analysis, conducted by Zając et al., has displayed a significant increase in using OTC drugs among junior high school students (13-15 years age bracket). In addition, girls were more inclined towards using such medicaments than boys [19]. Interesting results have been found by Finnish authors in a study examining the use of painkillers by the inhabitants of Finland. As many as $8.5 \%$ of the respondents admitted that they use such medicaments every day, and $13.6 \%$ take them several times per week. Moreover, the frequency of taking prescribed drugs was $8.7 \%$, and that of non-prescribed painkillers was 8.8\% [20]. In the study presented by Antczak et al., as many as $53 \%$ of the respondents declared that if any healthrelated symptoms occur (pain or a cold), they try to mitigate them with OTC drugs [1].

It may be surprising that women were more sceptical than men about the reliability of information pro- vided in the advertisements of OTC drugs. And yet, convinced by the commercials, they buy such medicaments more often. Undoubtedly, all marketing techniques used by pharmaceutical companies are aimed at encouraging potential customers to buy products of a particular manufacturer [17]. In addition, the study conducted by Chaniecka and Czerw gives grounds to the statement that the majority of the respondents have a positive attitude towards commercials for OTC drugs. These conclusions correspond with the findings of the authors of this study, in which women presented a negative approach as regards the reliability of the OTC drug commercials [21].

Other studies stress that only a small number of respondents had no contact with OTC drugs during the last month [22]. In this study, the authors found that the medicaments most frequently purchased by the respondents included painkillers and drugs against colds. Also, the results obtained by other authors are interesting - the most popular OTC drugs among young consumers are painkillers, cold and flu medicaments, remedies for gastro-intestinal disorders, and sleeping pills [23]. Analysis of our own studies revealed the necessity of providing education on the use of OTC drugs without a doctor's advice in various age groups [22]. The foreign reports indicate that in 2008 intoxication by OTC drugs was the second most frequent cause of death in the United States, preceded only by car accidents. The increased scale of intoxication is mainly induced by using opiate painkillers in order to mitigate pain [24].

According to the data of CBOS (Public Opinion Research Centre), as of 2010, more than a half of the population of Poland declared their health condition as good, and only $15 \%$ as poor. This latter group included mainly seniors, people with low education, and those who are dissatisfied with their financial status or view it as bad. In addition, the study conducted by CBOS reveals that when a person's health condition deteriorates as a result of health disorders, then as many as $31 \%$ of the respondents undertake various forms of self-treatment (home remedies), 30\% - mainly elderly - seek professional advice, and 24\% - usually young people - use OTC medicaments [25].

\section{Conclusions}

Based upon the conducted study, it is possible to present the following conclusions: using medicines without prescription is a widespread phenomenon, both among women and men. The two groups of drugs most frequently consumed by the respondents are painkillers and remedies for colds. The obtained results clearly indicate that commercials have a significant impact upon the recipients, and they stimulate the consumption of OTC drugs. It is becoming necessary to develop prophylactic measures in the scope of using medicines without a doctor's advice. An essen- 
tial element of such measures must be education of rational self-treatment and consultation with a physician in charge. It is necessary to extend and solidify social knowledge on the rational use of OTC drugs. Consumers who know the benefits and risks of using such remedies will be able to make the right choice from the medicaments that are available on the pharmaceutical market.

\section{Conflict of interest}

The authors declare no conflict of interest.

\section{References}

1. Antczak M, Kapsiak K, Kałucka S. Self-medication among university students in Lodz. Problemy Medycyny Rodzinnej 2013; 15: 34-9.

2. Krzysztoszek J, Matecka M, Matschay A, Jakubek E. Zachowania zdrowotne związane $\mathrm{z}$ samoleczeniem w okresie starości. Nowiny Lekarskie 2012; 81: 412-7.

3. Chomont K, Grzebieluch J. Analiza procesów kształtowania cen leków na rynku farmaceutycznym w Polsce. Część I. Piel Zdr Publ 2011; 1: 353-7.

4. Robinson RG. Pain relief for headaches. Is self-medication a problem? Can Fam Phys 1993; 39: 867-71.

5. WSMI Declaration on Self-care and Self-medication, 2006, WSMI. [available at: 23.09.2014] http://www.wsmi. org/pdf/boarddeclarationselfcare.pdf

6. Barbosa Servidoni A, Coelbo L, de Lima Navarro M, et al. Self-medication profile of ENT patients. Rev Bras Otorrinolaringol 2006; 72: 83-8.

7. Ciszowski K, Gomółka E, Jenner B. Wpływ dawki, czasu od zażycia i stężenia ksenobiotyku na stan kliniczny i stopień uszkodzenia wątroby u pacjentów zatrutych paracetamolem. Przegl Lek 2005; 62: 456-60.

8. Szkolnicka B, Mitrus M, Morawska J, et al. Zatrucia substancjami chemicznymi u dzieci w 2004 roku - konsultacje toksykologiczne. Przegl Lek 2005; 62: 564-7.

9. Prusiński A. Polekowe bóle głowy z odbicia. Alkoholizm i Narkomania 2002; 15: 271-6.

10. Szkolnicka B. Leki na receptę i dostępne bez recepty jako przyczyna prób samobójczych i niezamierzonych nadużyć - badania wstępne. Przegl Lek 2005; 62: 568-71.

11. Pisarska A, Ostaszewski K. Stosowanie wybranych leków przez 15-letnich uczniów szkół warszawskich. Alkoholizm i Narkomania 2006; 19: 53-70.

12. Cieślik A. Osobowość a sposoby radzenie sobie ze stresem. Studia Medyczne 2014; 30: 57-60.

13. Potocka-Banaś B, Majdanik S, Korwin-Piotrowska K, et al. Nadużywanie popularnych leków dostępnych bez recepty nowym trendem wśród młodzieży. Roczniki Pomorskiej Akademii Medycznej w Szczecinie 2013; 59: 114-9.

14. Sheen CL, Dillon JF, Bateman DN, et al. Paracetamol toxicity: epidemiology, prevention and costs to the healthcare system. QJ Med 2002: 95: 609-19.

15. Orange County Prescription Drug Task Force Prescription Drug Strategic Planning Session Attendees. County of Orange Health Care Agency Alcohol and Drug Education and Prevention Team (ADEPT). Available at: http:// ochealthinfo.com/adept/publications [23.09.2014].
16. Prescription and over the counter medications. Available at: http://www.drugabuse.gov/publications/research-- reports/prescription-- drugs [23.09.2014].

17. Czerw A. Marketing w ochronie zdrowia. Wydawnictwo Diffin, Warsaw 2010.

18. Michalik M, Pilarczyk B, Mruk H. Marketing strategiczny na rynku farmaceutycznym. Wolters Kluwer Business, Warsaw 2011.

19. Zając M, Andrzejczyk A, Kuich A, et al. Rekreacyjne stosowanie dekstrometorfanu - ocena na podstawie doświadczeń internautów. Przegl Lek 2013; 70: 525-7.

20. Turunen J, Mantyselka P, Kumpusalo E, Ahonen R. Częste stosowanie leków przeciwbólowych na poziomie populacji - częstość występowania i formy stosowania leków. Ból 2005; 6: 374-81.

21. Chaniecka KA, Czerw A. Płeć a postrzeganie reklamy telewizyjnej leków OTC. Hygeia Public Health 2013; 48: 509-14.

22. Wojtowicz-Chomicz K, Borzęcki A. Stosowanie leków przeciwbólowych z grupy OTC przez studentów Wydziału Lekarskiego UM w Lublinie. Fam Med Prim Care Rev 2011; 13: 254-6.

23. Bażydło M, Żułtak-Bączkowska K, Zaremba-Pechmann L, et al. Analiza stosowania leków OTC bez konsultacji z lekarzem w poszczególnych grupach wiekowych oraz ocena zapotrzebowania na edukacje zdrowotna w tym zakresie. Fam Med Prim Care Rev 2010; 2: 127-30.

24. Hollis DJ. Prescription and over-the-counter drug abuse strategic plan. Available at: http://www.michigan.gov/documents/mdch/RxOTC_Drug_Abuse_Strategic_Plan_Final_389362_7.pdf [23.09.2014].

25. Centrum Badania Opinii Społecznej. Stosowanie leków dostępnych bez recepty. CBOS 2010; 143: 2-15.

\section{Address for correspondence:}

Prof. Monika Szpringer PhD

Department of Social Prophylaxis

Institute of Public Health

Jan Kochanowski University

Al. IX Wieków Kielc 19, 25-317 Kielce, Poland

E-mail: mszprin@poczta.onet.pl 